\title{
Perception of Ijaw Youths toward Newspaper Reportage of the Niger Delta Conflict, Nigeria
}

\author{
Ofem, O. O.* \\ Department of Mass Communication, Cross River University of Technology, Calabar, Cross River State, \\ Nigeria
}

*Corresponding Author: Ofem, O. O., Department of Mass Communication, Cross River University of Technology, Calabar, Cross River State, Nigeria

\begin{abstract}
The media play central role in the reportage of day to day activities of Nigerian government as well as events of the Ijaw youth insurgency of the Niger Delta conflict. The paper assessed the perception of Ijaw youth towards newspaper's reportage of the Niger Delta conflict during the years of conflict intensity (2006-2007). Clustered sampling approach was employed to administered 293 questionnaire copies to respondents (Ijaw youths) in Bayelsa, Rivers and Delta states. Result showed that $73.4 \%$ of the respondents closely followed the Niger-Delta struggle and were able to adequately access the various print media in their respective domain. Majority of the respondents (95.2\%) perceived the media contents of the three selected publications as being biased and inconsistent in their reportage during the period of the conflict. The result further showed that $80.5 \%$ of the respondents were unsatisfied with the contents of the media reportage because they believed the media did not expressed or report the exact events and situations in the area. The study identified inability of the media to adopt a concise language and propaganda in reportage as well as timeless of reportage as the perceived factors that affected the contribution of conflict parties to conflict resolution.
\end{abstract}

Keywords: Niger Delta Conflict, Ijaw Youth, Reportage, Perception

\section{INTRODUCTION}

Globally, newspaper reportage is expected to be within the limits of media ethics while informing and educating the public on diverse societal issues like resource conflicts. The news feeds of many newspapers mostly during the heat of the Niger Delta conflicts were known for publishing untruth, half truth and distorted stories. On this note, more often than not, news events which several newspapers present or publish do not agree with the public perception of the actual news events (Anyadike, 2013). Newspaper reporters identify with and accept ideas, attitudes and opinions of associates, politicians and political associations at the detriment of ethical principles of reportage. This act makes people to lose confidence in the media which many expect to be an arbiter. This becomes more worrisome if the paper has government coverage. The objectivity of the media and their reportage can facilitate peaceful, cordial and favourable business environment devoid of bickering and discontentment through reporting undistorted but reliable, objective and balanced reports of the conflict situations in the Niger Delta Region (Anyadike, 2013). These are necessary ingredients that propel friendly conflict resolution. Based on ethical philosophy, a newspaper that is found to be neutral, unbiased, factual or objective and accurate in reporting issues is likely to attract favourable audience and patronage.

The media has contributed a great deal to the development of conflict because conflict remains attractive to the media (Owen-Ibe, 2003). The role of the media in conflict has been to communicate the events of conflict to interested readers and conflict parties who sometimes find the media a major source of the conflict awareness to a larger audience and interaction with the media itself and other parties to the conflict. The Niger Delta conflict which is the longest resource dispute in Nigeria has taken series of dimensions: from open agitation for resource control by Niger Delta activists to aggression resulting to confrontation between the activists with beneficiaries of the abundant resources of the region as well as those who tend to intervene negatively on the issues of resource control of the region by the activists and people of the region. The facts and basis for interaction on the events of the conflict is preeminent on the historical accounts of the conflict which has as well 
become the roots of the Niger Delta resource struggle and growth of the insurgency among the Ijaw youth of the Niger Delta.

The success of conflict resolution may sometimes depend on the role the media chooses to play (Otufodunrin, 2013). Depending on a number of factors, including ownership, interests of journalists, understanding of the issue in dispute and others, the media can decide to take sides in a conflict and make it impossible for it to be easily resolved. The media can choose to inflame passion through sensational reports informed by commercial interests, be used as propaganda tool through publication or broadcast of falsehood and undermine efforts to resolve conflicts (Otufodunrin, 2013). The information and education role of the media provides it with a major opportunity to help resolve conflicts, especially when the ethics of the profession are strictly adhered to. The ethics of the profession demands among others that media professionals should the truthful, accurate, fair and balance in their reports and broadcast. Unfortunately, this is not the case in many media reporting of conflicts. Instead of helping to resolve conflict, the media most times end up helping to complicate the situation. The notion that bad news sells probably explains why media will sometimes prefer that a crisis last longer than it should (Otufodunrin, 2013).

In the Niger Delta conflict, the Ijaw Youth has become a necessary study, as a basic factor in the militarization and opposition of government and her institutions over oil exploration in the region. In 1998, an All Ijaw Youth Conference intensified the Ijaws' struggle for resource control. The Ijaw Youth Council (IYC) which was subsequently formed, made a secessionist attempt (referred to as the Kaiama Declaration) set out to free the Ijaw nation from external intervention and exploitation. The IYC, according to Naficy (2003) pledged "to struggle peacefully for freedom, self-determination and ecological justice. While the operation lasted, a troop of soldiers were mobilized by government to Yenagoa, the Bayelsa capital, and on the 30th of December, opened fire on processing youth in the state capital and a further attack on the defiant youth continued leading to more casualties of the Ijaw Youth. The height of the conflict between government and the Ijaw Youth led to the Odi massacre of 1999 and scores of deaths among other casualties which further escalated the Niger Delta conflict.

The press as a medium of communication between disputants and considering its interest in the reportage of conflict acts like a mediator, intervener, and a facilitator and conflict analyst. It enlightens conflict parties, mediators on conflict issues and in most cases creates intervention tracks which the audience and mediation experts may not have known. Effective flow of media role in the communication of conflict requires 'objectivity and truth as good qualities of journalism' which Akin (2006) identified and according to him, a wrong word or misconceived message is one of the most common causes of conflict escalation. As conflict is basically a defect in communication. The inevitable role of communication and conflict requires the performance of a neutral third party who must act like an unbiased judge and mediator, for the effective performance of the society. The reliance on the media as a viable tool and instrument of concern for all strata of the society has been laid with series of complaint from both victims of media exploit and those that seem to applaud the existence of the media.

However, due to the subjectivity and biased nature of some media houses, people seem to show less concern to their newlines. According to Ajaero et al., (2016) evidence from studies in Nigeria indicates that people seem to have a negative perception of media reportage of issues. For instance, Afolabi (2010) noted that the mass media have not been timely in their reportage of conflicts and insurgencies. Other researchers also show that the Nigerian media have not effectively played a surveillance function in the reportage of conflicts and insurgencies, neither have they displayed a high level of objectivity in their reports (Oputa, 2011; Hamida and Baba, 2014). This according to Ajaero et al., (2016) can partly be attributed to the fact that most media organizations in the country are owned by state (sub-national) governments and individuals, and as such, they are primarily used to promote the interests of their owners. This to a large extent affects the language used in the reportage of issues in concern areas. The media as the fourth estate of the realm is susceptible to manipulation positively and otherwise, regardless of place and time. This is partly why media-conflict study is gaining currency globally. The role of the media in conflict prevention, resolution and escalation is now of global concern to both peace and conflict scholars and public policy makers. The kind of information the media disseminate is critical to sustaining peace and harmony in society and vice versa (Akpan et al., 2013). 
Thus, the benefits of media existence are sometimes totally misplaced, leaving public views to the assumption that the media is basically set for itself. Parties to the Niger Delta conflict are in this regards not exempted from this negative view of the press position in conflict reportage by conflict parties. However, reasons for media interest in conflict are sometimes not investigated, thus leaving public's assumptions of media interest as basically economic and not people oriented. On the other hand, the media seem to face series of challenges which it fails to tell the public, again the public requires relevant information on media position in conflict even if her position is privately motivated. This will at the end absolve the media from blame. In this context, the perception of conflict razed population based on mass media reportage is indispensable in reducing the extent of future conflict. Therefore, the aim of this study is to appraise Ijaw youths perception of newspaper reportage of the Niger Delta conflict. To achieve this aim, the study specifically seeks to examine ijaw youths' access to print media, their level of familiarity with the print media, Ijaw youth reception and perception of the media content and media language use in conflict understanding and impairment of media intervention.

\section{Materials ANd Methods}

\subsection{Design of the Study}

The study employed the descriptive cross sectional survey design. The purpose of descriptive survey is to collect detailed and factual information that describes an existing phenomenon.

\subsection{Sampling Technique}

Purposive and cluster sampling techniques were used. Purposive sampling technique was used to Bayelsa, Rivers and Delta states. These states were selected because they had the largest population of the Ijaw people. Cluster sampling approach was employed to administer the structured questionnaire copies to 293 respondents (Ijaw youths) across the three selected states. Ijaw youths were approached in different gatherings such as football field, viewing centres, recreational centres, houses and bars.

\subsection{Method Of Data Collection}

The structured questionnaire was personally administered to the target population with the help of three field assistants. After the purpose of the survey had been explained to the respective respondents and consent for the survey was given, the questionnaire was administered to the respondents.

\subsection{Data Analysis}

Data obtained from the administered questionnaire was analysed using tables and simple percentages.

\section{RESUltS}

\subsection{Socio-Demographic Characteristics}

The socio-demographic characteristics of respondents to a greater extent determine their level of knowledge of the Niger-Delta conflict. This is because those who are educated have high income may be predisposed or have readily access to information via the print media on the causes and media reportage of the Niger-Delta conflict. This group of people as a result of their education and high income as well as familiarity with the print media is believed to be privy to the print media and as such is well-informed or knowledgeable on the Niger-Delta conflict. People who are poorer and who have less education are more likely to ill-informed. Information on the socio-demographic characteristics of respondents is shown in Table 4.1. The sex distribution showed that males dominated the survey as they constituted 224 respondents representing 76.5 per cent, while female constituted 69 respondents representing 23.5 per cent. On the age of respondents, the study indicated that respondents within the ages of 35 - 44yrs dominated the survey, followed closely by those within the ages of $25-34 \mathrm{yrs}$, while those above the ages of $44 \mathrm{yrs}$ and $15-24 \mathrm{yrs}$ had the lowest number respectively. It could therefore be deduced that majority (71.3\%) of the people surveyed were within the ages of $25-44 \mathrm{yrs}$; implying that young adults constituted the survey. In addition, the educational status revealed that the respondents had different qualifications with majority of the respondents precisely 89.8 per cent with post-primary education. The pattern that emerged indicated that respondents with first degrees had the highest percentage (50.5\%) followed by those with secondary education (26.6). The study showed that 8.2 per cent of respondents had masters and $\mathrm{PhDs}$. In all, the implication of this result is that there is high level of literacy this is expected to have some influence 
on the people's level of knowledge concerning the Niger-Delta conflict and their assessment of the media reportage and language use.

Table1. Socio-demographic characteristics of respondents

\begin{tabular}{|c|c|c|c|}
\hline Variables & Category & Frequency & $\%$ \\
\hline \multirow[t]{2}{*}{ Sex } & Female & 69 & 23.5 \\
\hline & Male & 224 & 76.5 \\
\hline \multirow[t]{4}{*}{ Age } & $15-24 \mathrm{yrs}$ & 42 & 14.3 \\
\hline & $25-34 y r s$ & 80 & 27.3 \\
\hline & $35-44 y r s$ & 129 & 44.0 \\
\hline & $>44 \mathrm{yrs}$ & 42 & 14.3 \\
\hline \multirow[t]{7}{*}{ Education } & No education & 8 & 2.7 \\
\hline & Primary education & 22 & 7.5 \\
\hline & Secondary education & 78 & 26.6 \\
\hline & First Degree & 148 & 50.5 \\
\hline & Masters & 15 & 5.1 \\
\hline & $\mathrm{PhD}$ & 9 & 3.1 \\
\hline & OND, NCE/Diploma & 13 & 4.4 \\
\hline \multirow[t]{7}{*}{ Occupation } & Trading & 9 & 3.1 \\
\hline & Farming & 47 & 16.0 \\
\hline & Students & 53 & 18.1 \\
\hline & Teaching & 15 & 5.1 \\
\hline & Civil servant & 41 & 14.0 \\
\hline & Fishing & 100 & 34.1 \\
\hline & Unemployed & 28 & 9.6 \\
\hline \multirow[t]{6}{*}{ Monthly Income } & $<\mathrm{N} 50,000$ & 86 & 29.4 \\
\hline & $\mathrm{N} 50,000$ - N100,000 & 44 & 15.0 \\
\hline & $\mathrm{N} 100,100$ - N150,000 & 90 & 30.7 \\
\hline & $\mathrm{N} 150,100$ - N200,000 & 32 & 10.9 \\
\hline & $\mathrm{N} 200,100$ - N250,000 & 5 & 1.7 \\
\hline & No income & 36 & 12.3 \\
\hline \multirow[t]{2}{*}{ Ijaw indigene } & Yes & 239 & 81.6 \\
\hline & No & 54 & 18.4 \\
\hline \multirow[t]{4}{*}{ Years of residence for non-Ijaws } & Not applicable & 239 & 81.6 \\
\hline & $6-10 \mathrm{yrs}$ & 13 & 4.4 \\
\hline & $11-15 y r s$ & 19 & 6.5 \\
\hline & $>15 \mathrm{yrs}$ & 22 & 7.5 \\
\hline
\end{tabular}

On occupation, the result in Table 4.1 showed that the occupational pattern was dominated by fishermen/women with 34.1 per cent, followed by students, farmers and civil servants with 18.1, 16.0 and 14.0 per cent respectively. It therefore implies that 82.2 per cent of the respondents are engaged in the above mentioned occupations, while those who are teachers and unemployed constitute 5.1 and 9.6 per cent respectively. From the result it implies that people in the study area engage in various occupations as sources of likelihoods; the dominance of fishing is a topical characteristics of riverine communities or communities found along the riverside. The monthly income of respondents also showed a varied pattern (Table 4.1). It showed that a larger percentage $(30.7 \%)$ of the respondents in the area earned N100, $100-\mathrm{N} 150,000$ monthly, this was followed by those that earned $<\mathrm{N} 50,000$ monthly, while the least monthly income was N200,100 - N250,000. This difference in income may be attributed to the variation in the nature of occupation. In all, the study shows that a larger number of the people in the area of study earn less than <N50, 000 to N200, 000 monthly. Very few are found by this study to earn above N200, 000 monthly.

Information on respondents who are Ijaw indigenes showed that the Ijaws dominated the survey which was unconnected to the area of the study which is predominantly occupied by the Ijaws who are indigenes. Similar dominance of a particular ethnic group was reported by Raheem (1999). Specifically, the result in Table 4.1 revealed that the Ijaws constituted 81.6 per cent, while the nonIjaws such as Igbos, Ibibios and Efiks among others made up 18.4 per cent. Further analysis on the years of residence of respondents who are not indigenes (i.e. non-Ijaws) revealed that out of the 54 non-indigenes, a larger number or percentage had been in the area for more than 15 year, followed by those that had resided in the area for $11-15 \mathrm{yrs}$, while the lowest had resided in the area for $6-10 \mathrm{yrs}$. 
From the pattern that emerged, it showed that majority of the non-indigenes had resided or lived in the area for 11 years and above.

\subsection{Assessment of Ijaw Youths Access to Print Media}

The Ijaw youths' access to the print media during the Niger-Delta conflict was assessed and the information obtained is shown in Table 2. The information showed that a larger percentage of the respondents had access to the print media implying that a larger number of the people surveyed were knowledgeable of the Niger-Delta conflict and would be able to provide or give reasonable details on the media content, level of reportage and media language among other issues that explained the agitations and insurgency of the conflict. In addition, the study indicated that a small percentage did not have access to the print media. However, discussion with some of the respondents showed that though, they did not have access to the print media, they have fair knowledge on the conflict since it was an issue that attracted global attention and an issue that has to do with them as their source of likelihood was greatly affected. This category of respondents alleged that they got information on the conflict from peers, age-grade meetings and other functions where matters concerning the conflicts were normally discussed or threw open for people to comment on. In all, the information provided above clearly implies that majority of the respondents followed closely the Niger-Delta struggle and are able to adequately access the various print media. This group of respondent can be inferred to have adequate knowledge on the conflict. Nevertheless, a little discussion with some of the respondents that indicated they had access to the print media indicated that the Vanguard was mostly read followed by the Niger-Delta standard and then the Guardian. They believed that the first two print media were somewhat directional and sincere in their reportage of the Niger-Delta conflict.

Table2. Assessment of respondents' access to print media

\begin{tabular}{|c|c|c|}
\hline Options & Frequency & Percent \\
\hline Yes & 215 & 73.4 \\
\hline No & 78 & 26.6 \\
\hline Total & $\mathbf{2 9 3}$ & $\mathbf{1 0 0 . 0}$ \\
\hline
\end{tabular}

\subsection{Level of Familiarity with the Print Media}

Since respondents' access to the print media has been established, their level of familiarity with the Guardian, the Niger-Delta Standard and Vanguard publications of 1997 - 2012 was ascertained. The result obtained is shown in Table 3. It showed that a large percentage $(66.6 \%)$ of the respondents were very well familiar with the three print media; 15.0 per cent were not very well familiar with the print media publications of the stated period, while 18.4 per cent were not in any way familiar with the publications of the print media from 1997 - 2012. The information simply suggests that though people have access to the print media, but not all of them are privy or opportune to be familiar with the publications of 1997 to 2012. However, the percentage of respondents who are familiar with the publications during this period is appreciable and helped to provide knowledge on the pattern of media reportage and consumer reception of the media content during this period. Also, by implication, those who are not very well familiar with the publications during this period $(1997-2012)$ means that they can to some extent help to give information on the happenings during this time period. Those who are not familiar at all with the publications relied on hear-say and as such, may not give concise information media reportage and consumer reception

Table3. Respondents' level of familiarity with the Guardian, the Niger Delta Standard and the Vanguard publications of 1997-2012

\begin{tabular}{|c|c|c|}
\hline Options & Frequency & Percent \\
\hline Very well & 195 & 66.6 \\
\hline Not very well & 44 & 15.0 \\
\hline Not at all & 54 & 18.4 \\
\hline Total & $\mathbf{2 9 3}$ & $\mathbf{1 0 0 . 0}$ \\
\hline
\end{tabular}

\subsection{Consumer's Reception and Perception of the Media Content}

Based on respondents' level of familiarity with the publications of the Niger-Delta conflicts, the researcher makes bold attempts to ascertain their reception as well as perception of the media content of the conflict (Table 4). The consumers in this context are the Niger-Delta youths who were to some extent knowledgeable of the publications of the Niger-Delta conflicts. On the reception of the media 
content, the result showed that a greater percentage (64.8\%) of the respondents was not very well received the media content of the conflict; 19.5 per cent were very well satisfied, while 15.7 per cent were not at all satisfied with the media content of the conflict. The result means that 80.5 per cent of the respondents are not in any way satisfied with the contents of the publication. This means that the print media may not have expressed or reported the exact events and situations as they occur or happen in the area of focus. This may mean that they media contents were not objective in their publications as such there news contents were not received by the Ijaw youths. Information on the perception of the media content revealed that 59.7 per cent were unsatisfied with the media style of reportage. This is because the respective media did not report or provide the exact facts and figures of casualties were not reported. This means that majority of the Ijaw youths perceived the contents of the print media as bias and characterized by preconceived notion and prejudice from the part of the journalists. Also, an appreciable number or percentage of the respondents perceived the media content as confusing and inconsistent making full understanding of the conflict difficult. In a related situation, Ogbondah (2003) as quoted in Ekanem (2008) stated that the politicization of news has become a growing problem in the Nigerian media. This together with corruption has encouraged bias in the coverage of news as well as severe dependence of journalist on government and political paymasters.

They alleged that the print media during this period gave conflicting and confusing information on the casualties and approaches taken by the government and the oil communities (Ijaw communities) to address the Niger-Delta conflict. This goes to buttress the assertion made by Ezeah (2007) that the question of fairness and accuracy seems to be the most abused of all the provisions of the ethical code by Journalists in Nigeria. The problem of inaccuracies and distortions of facts could be informed by the reporters' rush to the print without taking pains to check their facts. Perhaps, the inaccurate report during this period is seriously believed by the Ijaw Youths to cause destruction to the area and delayed government's amnesty programme that had a significant impact on the return of peace to the area. However, very few respondents had mixed feeling concerning the media content as on the one hand, they felt bad of the content published by the print media and on the other had praised the media for creating necessary awareness about the conflict which attracted regional, national and global attention and the need for the immediate and remote cause of the conflict to be addressed. In summary, the result in Table 4 shows that majority of the respondents perceived the media contents of the three selected publications as being biased and inconsistent in their reportage during the period of the conflict. In a related study, Anyadike, (2013) stated that the ability of the media to be objective and reliable facilitates peaceful existence devoid of bickering. He also stated that people tend to lose faith and confidence in the media when they observe their reports not objective but skewed towards a given direction. Such act can worsen or escalate conflict. Similarly, Otufodunrin (2013) stated that the media instead of helping to resolve conflict, most times end up helping to complicate the situation by reporting falsehood and this undermine efforts to resolve conflicts.

Table4. Assessment of consumers' reception and perception of the media content

\begin{tabular}{|c|c|c|c|}
\hline Variables & Category & Frequency & \% \\
\hline Reception of the media content & Very well & 57 & 19.5 \\
\hline & Not very well & 190 & 64.8 \\
\hline & Not at all & 46 & 15.7 \\
\hline Perception of the media content & Felt bad and created awareness & 14 & 4.8 \\
\hline & Unsatisfied with media reportage & 175 & 59.7 \\
\hline & Confusing \& inconsistency in media reportage & 104 & 35.5 \\
\hline
\end{tabular}

\subsection{Media Language Use in Conflict Understanding and Impairment of Media Intervention}

Respondents were asked if they think that the media language used in reporting the Niger Delta conflict affects their understanding of the development of the conflict; the result obtained showed varied response (Table 5). The result revealed that 25.9 per cent of the respondents were of the opinion that the media language used in reporting the Niger Delta conflict affects their understanding of the development of the conflict and 47.4 per cent did not feel that the language used in reportage affected their understanding of the development of the conflict, while 26.6 per cent did not know if the media language had any effects on their understanding of the development of the conflict. What this means is that many of the Ijaw youths do not see the media language as a problem in the reporting of the Niger-Delta conflict and many others seem to be careless of the media language as they happen not to know the consequence the media language could have on the conflict parties' understanding 
and contribution to the conflict. However, a significant others believe that conflict parties' understanding cum contribution to the conflict among the Ijaw youths is to some extent affected by the media language. This group of individuals suggests that the media language sometimes is incisive and disheartening mostly in seeing people in the area as opportunists. The general idea derived from this analysis is that majority of the Ijaw youths does not have the impression that the language used in reportage of the Niger-Delta conflict affected their understanding of the development of the conflict. This implied that the media language was simple and objective.

The reasons why the percentage of respondents alleged that the media language affected conflict parties' understanding cum contribution to the conflict are depicted in Table 5 The result identified inability of the media to adopt a concise language, the timeless of reporting and the propaganda in reporting as the main reasons why the media language affected the Ijaw youths understanding of the development of the conflict. The respondents believed that doing this time, the media was unable to use concise language in its reportage and most times, the language was misunderstood by the youths who could get agitated by the language used. They maintained that at some time, they came to a conclusion that the media was government puppet. On the timeless of reporting, they believed the inability of the media to instantly make public events that occurred in the area also affected the Ijaw youths' contribution to eschewing peace. The media language was further conceived by this group of respondents or Ijaw youths as basically propaganda resulting in misinformation of the wider society of the exact happenings, immediate and remote cause of the Niger-Delta struggle. This misinformation propelled by the media via its language according to this individual did not augur well and actually affected conflict parties' understanding cum contribution to the conflict. The style of reportage was another factor that affected conflict parties' understanding of the Niger-Delta conflict. In concise, the factors listed and discussed above to some extent actually affected the contribution of conflict parties to conflict resolution because the media language was unsatisfactory and unsavory, and when used, it triggered reactions from the youth thereby worsening the conflict. Anyadike, (2013) also noted that the media language is a serious determinant of peace coexistence.

Table5. Media language use, understanding and media intervention into the Niger-Delta conflict

\begin{tabular}{|c|l|c|c|}
\hline \multicolumn{1}{|c|}{ Variables } & \multicolumn{1}{|c|}{ Category } & Frequency & \% \\
\hline Assessment of media language & \multicolumn{1}{|c|}{ Yes } & 76 & 25.9 \\
\hline & \multicolumn{1}{|c|}{ No } & 139 & 47.4 \\
\hline $\begin{array}{l}\text { Ways the misinterpretation of media } \\
\text { language impaired media intervention }\end{array}$ & $\begin{array}{l}\text { Inability of the media to adopt a concise } \\
\text { language }\end{array}$ & 31 & 26.6 \\
\hline & The timeless of reporting & 11 & 14.5 \\
\hline & The style of reporting & 7 & 9.2 \\
\hline & The propaganda in reporting & 27 & 35.5 \\
\hline
\end{tabular}

\section{CONCLUSION}

The study has shown that a larger percentage of the Ijaw youths have access to the print media and their desire to have access to the media is premeditated due to the fact that the Niger Delta issue has attracted global attention and is an issue that has to do with them as their source of likelihood was greatly affected. It also means that the youths follow closely the Niger-Delta struggle which has remain their aspiration as a nation. It has shown that the Ijaw youth generally have negative perception concerning the media reportage of the Niger Delta Conflict. This is so as majority of the youths are not in any way pleased with the contents of the media publication. This simply suggests that the print media has not expressed or reported the exact events and situations as they occurred or happened in the area of focus. This may mean that they media contents were not objective in their publications as such there news contents were not received by the Ijaw youths. The youth are of the opinion that the print media reported conflicting and confusing stories and published false information on the casualties and approaches taken by the government and the oil communities (Ijaw communities) to address the Niger-Delta conflict. The contents of the three selected publications are perceived by the youths as subjective and have conflicting stories in their reportage during the period of the conflict. The media language employed by the media is believed by the youth not to affect their understanding of the development of the conflict. This implied that the media language was simple and partly objective. 


\section{REFERENCES}

[1] Afolabi, R. B. (2010) Mass media coverage of crises in Nigeria. Journal of Conflict Studies, 8(5), 51-65.

[2] Ajaero, I. J., Okoro, N. M and Ajaero, C. K. (2016) Perception of and attitude toward mass media reportage of the 2012 flood in rural Nigeria. SAGE Open: $1-8$.

[3] Akpan, F. U., Ering, S. O. and Olofu-Adeoye, A. (2013) The media and conflicts in Nigeria. International Journal of Asian Social Science, 3 (11): 2279 - 2287.

[4] Anyadike, D. O. (2013) Public perception of newspaper adherence to ethical principles in the reportage of electoral processes in south east Nigeria. New Media and Mass Communication, 17: 1 - 10.

[5] Ekanem, I. B. (2008) Press freedom: A catalyst for the sustenance of democracy in Nigeria. International Journal of Communication, 9: 66 - 74 .

[6] Ezeah, G. H. (2007) Codes of professional ethics and journalism practice in Nigeria. International Journal of Communication, 6: 51-57.

[7] Hamida, A. M. and Baba, I. M. (2014) Resolving Nigeria's "Boko Haram" insurgence: What role for the media? Procedia-Social and Behavioral Sciences, 155, 14-20.

[8] Oputa, I. L. (2011) The factor of objectivity in media coverage of Niger-Delta crisis. Journal of Media and Conflict Research, 7(4), 58-69.

[9] Otufodunrin, L. (2013) The role of the media in conflict resolution. Retrieved from: http://www. ufukfoundation.org/?sayfa=The_Role_of_Media_in_Conflict_Resolution

[10] Owens-Ibie N. (2002) Socio-cultural considerations in conflict reporting in Nigeria. Pate UA Ed. Introduction to conflict reporting in Nigeria. Lagos Friedrich Ebert Stiftung pp.30-44.

Citation: Ofem, O. O.. "Perception of Ijaw Youths toward Newspaper Reportage of the Niger Delta Conflict, Nigeria". International Journal of Media, Journalism and Mass Communications (IJMJMC), vol 4, no. 2, 2018, pp. 11-18. doi:http://dx.doi.org/10. 20431/2455-0043.0402002

Copyright: (C) 2018 Authors. This is an open-access article distributed under the terms of the Creative Commons Attribution License, which permits unrestricted use, distribution, and reproduction in any medium, provided the original author and source are credited. 